hypodermic method, from this point of view, is not distinctly superior to any other method."

I am, Sirs, yours faithfully,

New Cavendish-street, W., Nov. 5th, $1906 . \quad$ C. F. MARSHALL.

\section{THE SOILING OF THE LOAF.}

7o the Editors of THE LANCET.

SIRS,-I have no doubt many a householder interested in public-health questions is grateful to you for your recent article under the above heading. In this conservative old country it seems to be quite possible that public opinion has never been directed to this evil since Englishmen began to consider questions of domestic health, and since paper bags have been so inexpensive. Why should not the baker deliver a loaf of bread in a bag just as if it were a bun or a cake? Why should bread be taken to the customers' houses for seleotion? This is not done with regard to other articles of food supplied from shops, though it is a habit of street hawkers. Why does the cook or other servant want to prod the loaves on delivery with her unwashed hands? To feel if the selected loaf is crisp, to make certain that the baker is not substituting a stale article for a fresh one, or is it merely a conventional excuse for prolonging a flirtatious interview? You point out the risk which bread runs from contact with the baker's coat or handkerchief or with the mud or dust of the street, but there are other dangers to which the basket of unprotected bread may be subjected. A careful boy hangs his basket on the area railings while he is chatting with the maids, but it is no uncommon thing to see a basket waiting on a muddy, sputum-stained (? tuberculous) pavement, exposed to the urinary attentions of canine passers-by. For the needs of my own household a provider has been found who sends us "Farm-house" bread, each loaf wrapped in a paper bag, for which we pay nothing extra. I presume there are many bakers who would do this if invited by their clients. I am, Sirs, yours faithfally, F. M. SaNDWITH, M.D. Durh.

Cavendish-square, W., Nov. 13th, 1996

\section{To the Editors of THE LANCET.}

SIRS, - While you are advocating more purity in our bread-supply, any morning between 6 and 7 o'clock at a large bakery establishment there may be seen standing on the pavement in shallow trays, not so high as the loaves they contain, the morning delivery awaiting storage in the carts. The rotatory road-sweeping machines pass by, scattering upon them in dry weather the dust of the street, and the pavement sweeper goes in and ont among the trays with his brush, completing the dosage of germs. One morning lately I saw an assistant throw one of the loaves into a street corner at a passing cat, which loaf was then carelessly included in the stock. As this sort of thing may be of common practice in London, as you have the interest of the community at heart you may be glad to have this testimony from a frequent eyewitness who regrets he has not the power you have in the matter to put a stop to it. I know nothing of the bakery or its owners who probably themselves are quite unaware of the evils involved in it.

I am, Sirs, your obedient servant,

Clarence Gate, N.W., Nov. 9th, $1906 . \quad$ H. J. HUGH, Major.

\section{MORAU AND "JENSEN'S TUMOUR."}

\section{To the Editors of THE LANCET.}

SiRS,-Will you allow me to call attention to a typographical error in the abstract of my recent communication to the Pathological Society, "What is 'Jensen's Tumour'?" 1 in which the discoverer and original investigator of this interesting malady is referred to as Moran, instead of Morau? The just claims of Morau as the discoverer of this malady have been so generally overlooked in this country and in Germany that the malady he discovered and experimentally investigated is now commonly known as "Jensen's tumour," and this kind of misconception has lately received its apotheosis at the hands of the Council of the Royal College of Surgeons, who have just awarded the Walker prize to Jensen as its discoverer. Under these circumstances, I think it would be well if Jensen, recognising the fictitious state of things attaching to this award, were gracefully to decline its acceptance.

I am, Sirs, yours faithfully,

Clifton, Bristol, Nov. 10th, $1906 . \quad$ W. ROGER Williams.

\section{THE CASE OF MR. PEERS : A MISCARRIAGE} OF JUSTICE. ${ }^{1}$

To the Editors of THE LANCET.

SIRS,-In view of the marked injustice of the verdict in this case and in order to emphasise the sympathy of his professional brethren it is proposed to raise sufficient money to defray the cost of Mr. T. H. P. Peers's defence and to pay the damages awarded. A list will be published in THE LANCET of those gentlemen who have already promised assistance, and in the meantime any further donations will be gratefully received and acknowledged.

I am, Sirs, yours faithfully,

278, Old Kent-road, S.E.

C. H. Pring, M.A. Honorary Treasurer.

\section{MUNICIPAL MUDDLES.}

\section{To the Editors of THE LANCET.}

SIRS,-In The LANCET of Oct. 13th I notice that under the heading "Municipal Muddles" you make reference to the action of the Westminster district surveyor. Would you kindly note that the Westminster District Surveyor is not an official of the Westminster City Council but of the London County Council, and that the whole matter referred to is one which does not in any respect concern the Westminster Oity Council or come within their jurisdiction, but is entirely a matter under the control and administration of the London County Council. I have deemed it necessary to write you as I find that your paragraph has been generally taken to refer to the Westminster City Council.

\section{I am, Sirs, yours truly,}

C. SPENCER-SMITH,

Chairman of the Works Committee of the Westminster Palace-street, S.W., Nov. 13th, 1906.

$$
\text { City Council. }
$$

\section{HYPOCHLORITES PRODUCED BY ELEC- TROLYSIS AS DISINFECTANTS.}

\author{
To the Editors of THE LANCET.
}

SIRs,-You say in your remarks on our recent paper that you believe with Dr. Klein that the hypochlorites are powerful disinfectant agents even in the presence of organic matter. If you will refer to Public Health, October, 1906, you will see that Klein finds for chloros (the strongest solution of hypochlorites offered to the public) a carbolic coefficient in water of $21 \cdot 0$, but in urine $2 \cdot 2$ or $0 \cdot 8$, according to the conditions specified.

Anent your remarks on the inconsistent statements of certain bacteriologists who have worked with the method of standardisation used by us, it is quite true that several observers have obtained varying and various results. These discrepancies are the fault of the observer, not of the method. We have shown conclusively that where the conditions, as enumerated in our paper in Public Health of March, 1906, are strictly observed, the results are uniform. We are, Sirs, yours faithfully,

$$
\text { DAVID SOMMERVILLE. }
$$

Nov. 6th, 1906. J. T. AINSLIE WALKER

\section{THE AMERICAN ROENTGEN RAY SOCIETY.}

\section{To the Editors of THE LANCET.}

SIRS,-Your readers may be interested in some account of the annual meeting of this society which was held at Niagara Falls, New York, on August 29th, 30th, and 31st, at the Cataract Hotel, under the most perfect conditions of weather and surroundings. The attendance of members and visitors amounted to about 200, nearly all the States of the Union being represented as well as some foreign countries. The way to the large room where the meetings were held led through an ante-room arranged for the exhibition of radiographs, which is always an important feature of the annual meeting. No one could help being at once struck with the high degree of excellence which has been attained in this

1 A brief report of this case was published in THE LANCFT of Nov, 10th, 1906, p. 1301. 